\title{
The rally-intensive campaign: A distinct form of electioneering in sub-Saharan Africa and beyond
}

Pre-proof of article for publication in the International Journal of Press/Politics in May 2019

\author{
Dr. Dan Paget \\ Department of Political Science \\ University College London \\ danpaget.com \\ d.paget@ucl.ac.uk
}

The literature on political communication is a redoubt of modernist thought. Histories of political communication are in part histories of technological progress. Accounts, which are too numerous to list comprehensively here, rehearse a well-worn story in which newspapers are joined by radio, limited-channel television, multiple-channel television, the Internet and social media in turn (Dinkin 1989; Epstein 2018). Numerous authors have organized these successive innovations into 'ages' or 'orders' of political communication (Blumler and Kavanagh 1999; Epstein 2018). These modernist ideas bleed into the study of election campaigns. A series of accounts using parallel categories construct three ideal-types of election campaign (Norris 2000). These campaign types capture, among other things, changes in the methods by which messages are conveyed. 'Old' face-to-face methods of communication in 'premodern' campaigns are supplemented and sometimes replaced by a succession of 'new' methods in 'modern' and 'postmodern' campaigns.

These theories embrace a form of developmental linearity. They conceive of a single path of campaign 'evolution' (Norris 2000). While campaigns may progress or regress, campaign change 
is collapsed onto a single dimension, whether by the name of modernization or professionalization. It is this linearity that gives typologies of election campaigns their modernist character. It is also essential to these theories' parochialism. Media systems have been studied extensively beyond the Western world. However, typologies in the narrower domain of election campaigns remain remarkably Western-centric in both their source material and domains of application, albeit with notable exceptions (Plasser and Plasser 2002). In this article, I do not challenge the conventional causal accounts of campaign change. However, I complicate these typologies. I contend that their conceptual linearity obscures variation in another aspect of electioneering: ground campaigns. In these typologies, ground campaigns feature only by virtue of their centrality in premodern campaigns and their peripherality in modern and postmodern campaigns. However, ground campaigns vary. In some, politicians reach few citizens directly at rallies. Instead, the rally is primarily a device to win media coverage. It is used almost exclusively by party leaders, if it is used at all. By contrast, in other ground campaigns, the rally is a medium through which junior and senior politicians alike interact directly with large portions of their constituents. For example, on the eve of Turkey's 2018 election, an estimated million people attended one rally (Shaheen 2018). In India's 2019 campaign, an estimated half million people attended another (Al Jazeera 2019). Rallies are important features of some Latin American campaigns (de la Torre and Conaghan 2009; Szwarcberg 2012). Data that I present below reveals that aggregate rally attendance is high in many Asian countries, and higher still in many African countries.

However, existing typologies of election campaigns cannot satisfactorily express this variation in ground campaigns. I revise Norris' typology to address that shortcoming. This adapted typology creates the conceptual space to incorporate a distinct ideal-type: the rally-intensive campaign. This proposed revision moves the center of gravity of the schema from the Global North towards the Global South. It equips the typology to capture important aspects of campaigns in 
parts of sub-Saharan Africa, Latin America, and Asia. It gives expression to differences between these campaigns and their Western counterparts. Equally, it makes important distinctions within the population of 'premodern' election campaigns. Therefore, it speaks to the debate about electioneering in the Western world, and widely-accepted accounts of the main features of historic campaign evolution.

While the prominence of the rally is intercontinental, it is most pronounced in parts of subSaharan Africa. In spite of this, the means through which political messages are conveyed are little studied in the Africanist literature. Some of the last major works to study the structure of face-to-face communication in sub-Saharan Africa were written before the third wave of democratization and the revival of multiparty campaigns (Ellis 1989; Haugerud 1995). While their insights remain pertinent, they deserve updating. A rich body of work has developed which examines electioneering in multiparty sub-Saharan Africa. However, the great majority of these studies focus on parties' messages or appeals. The means and media by which parties convey those messages in the campaign are little-studied. This is my point of departure from the Africanist literature. I seek to restore the character and structure of campaign communication in general and ground campaign communication in particular to the study of African electioneering. I argue that in many African campaigns, the rally is the primary medium of direct campaign communication. This structural aspect of campaign ecology underpins a variety of other features of the ground campaign. Equally, the prominence of the rally is a source of substantial variation between African campaigns; while some are rally-intensive, others are not.

Typologies should make distinctions which turn on fundamental characteristics alone. I argue that aggregate rally-intensiveness is associated with four typical features. I demonstrate this through a detailed study of an extreme case (Flyvbjerg 2006): Tanzania. If the survey data is correct, Tanzania has the most rally-intensive campaigns in Africa, and to the best of my 
knowledge, the world. I distil the four features of the rally-intensive campaign by observing the stark form that they take in the Tanzanian case. First, drawing on my ethnographic research, I show that not only national leaders dedicate substantial effort to convening rallies. Mid- and lowlevel candidates do too. Therefore, during each day of the campaign, thousands of rallies are convened, both locally and nationally. Second, using original survey data, I show that local rallies are better attended in aggregate than national ones. Consequently, in rally-intensive campaigns, a large proportion of campaign contact is not only direct but intimate. Third, I show that in rallyintensive campaigns the mass meeting dwarfs the canvass as a form of campaign contact. Fourth, I illustrate that Tanzanian parties' ground campaign efforts are concentrated not on canvassing, but on a bundle of activities which I term the 'production' of rallies. Thereby, this paper deals in what John Gerring ironically describes as 'mere description' (Gerring 2012). It takes the categorization and characterization of campaigns as an academic end in itself.

I proceed in this article by introducing the comparative typologies of election campaigns. In the second section, I juxtapose these works to the literature on election campaigning in sub-Saharan Africa to throw into relief the relative silence of the latter on ground campaign contact. In the third section, I present my departure from both of these literatures. I argue that aggregate rally attendance varies. It varies between the Global South and the contemporary Western world, within sub-Saharan Africa, and within the population of historic 'premodern' campaigns in Western countries. I argue that existing campaign typologies obscure, rather than order, this variation. I advance a typology of campaign ecologies adopted from Norris' own which incorporates the rally-intensive campaign as a distinct ideal-type. In the fourth section, I enumerate typical features of the rally-intensive campaign by presenting evidence from my research in Tanzania. 


\section{Typologies of election campaigns}

Pippa Norris advances a typology of premodern, modern, and postmodern campaigns (Norris 2000). Rachel Gibson and Andrea Römmele distinguish between premodern, modern and professional campaigns in almost identical terms (Gibson and Rommele 2001). Similarly, David Farrell and Paul Webb have advanced three 'stages' of election campaign professionalization (Farrell and Webb 2000). In parallel, Jay Blumler and Dennis Kavanagh identify three 'ages of political communication' (Blumler and Kavanagh 1999) and Ben Epstein enumerates four 'political communication orders' (Epstein 2018). Typologies of political communication have broader scopes than typologies of election campaigns. Nonetheless, these typologies agree in numerous respects. Each, save Epstein's, enumerates three categories. ${ }^{i}$ Each takes the proliferation of limited channel television as the dividing line, or part of the dividing line, between the first and second categories. Equally, each takes the multiplication of television channels, the diffusion of the Internet, and related developments as the dividing line, or part of the dividing line, between the second and third categories. ${ }^{\text {ii }}$ They identify similar sets of features as characteristic of each category too. Norris takes the media and means of communication, party campaign activity, political party organization and the behavior of the electorate as the distinctive characteristics of each type of campaign. Gibson and Römmele use terms that are commensurable with, though not identical to, Norris'. Farrell and Webb differ from Norris' only by excluding behavior of the electorate from their list of typical features and including the character of parties' messages. Blumler and Kavanagh differ from Norris by including the content of politicians' messages and excluding party organization.

Disagreements remain about whether the differences between the contents of each category are best summarized as degrees of modernization or professionalization. However, a close reading reveals that these five sets of authors employ the languages of both modernization and 
professionalization as they describe their categories. Therefore, there is much that these typologies share. I introduce this literature by summarizing Norris' typology of campaigns, both because her typology is most pertinent to the discussion that follows, and for simplicity's sake.

The typology that Norris offers is descriptive rather than causal. It concerns what each type of campaign is, rather than why it comes into being. Norris also advances parallel claims about the 'evolutionary processes of modernization [emphasis in original]' that drive transition from one campaign type to another (Norris 2000:137). However, these causal claims are distinct from her definitions of those campaign types themselves. In Norris' premodern campaign, the newspaper is the dominant mass medium. Other mass media either have limited penetration or are absent altogether. Accordingly, party-voter contact is direct, rather than indirect, and electioneering is 'local-active'. The premodern campaign is accompanied by 'constituency-oriented' party organization typified by cadre and mass parties. It also corresponds to particular forms of voter behavior; citizens form partisan social blocs with steadfast loyalties and selective media diets.

In modern campaigns, 'direct forms of personal communication... became supplemented by television. The main effort of party campaign organizations... focused on achieving favorable coverage on the mainstream evening news' (Norris 2000:145). This change in party campaign ecology corresponds to changes in party organization. Parties adapt to privilege the iconic role of the leader. The strategic role of both party leadership and professional consultants increases (Norris 2000:145-6). Lastly, modern campaigns are typified by different electorates which are less partisan and more passive. These voters enjoy more neutral, homogenous media diets dominated by limited-channel television. In postmodern campaigns, media environments fragment. Channels and media proliferate, and audiences narrow. Increasing choice in media is connected to increasingly diverse electorates. Postmodern campaigns involve efforts by political parties to 
design messages that are more local, interactive, and responsive to these narrower segments of the electorate.

Not only do the typologies advanced by these authors have much in common. Their categories remain largely undisputed. A burgeoning field has updated and complicated many of the characterizations of postmodern campaigns advanced by Norris and others (Chadwick 2013; Gibson, Römmele, and Ward 2004; Vaccari 2013). Many stress the contingent relationship between technology and campaign methods (Epstein 2018; Karlsen 2010; Vaccari 2013). Nonetheless, most of these authors locate their studies in what they describe variously as the third age, Internet politics, digital politics, electronic democracy or hybrid media systems (Chadwick 2013; Gibson, Römmele, and Ward 2004; Vaccari 2013). Further still, this periodization of historic campaigning has gone largely unchallenged by recent analytic histories of election campaign innovation (Epstein 2018; Strömbäck 2008).

Perhaps the greatest departure from these typologies is by Fritz and Gunda Plasser (Plasser and Plasser 2002). They contend that parties select 'special aspects of media- and consultant-driven campaign practices' and combine them with 'country- and culture-specific traditional campaign styles' (Plasser \& Plasser, 2002:348). This leads to hybrid campaigns, not unlike those described by Carlos de la Torre and Catherine Conaghan (de la Torre and Conaghan 2009). Plasser and Plasser identify five campaign styles which arise from this hybridity: American, West European, Central and Eastern European, and East Asian styles, and a final style which they identify in South African and Indian campaigns.

\section{Election campaigning in sub-Saharan Africa}


While the literature that I have described above is sometimes characterized as comparative, in fact, it is dominated by studies of economically advanced countries in the Western world. Indeed, many of the studies which I have described above, including Norris', explicitly limit their domains of application to the West or some equivalent category such as 'post-industrial societies'. In this article, I consider how to characterize and classify sub-Saharan African election campaigns in particular, and others like them.

Studies of African election campaigns in the 1950s and 1960s emphasized the paramount importance of rallies (Mackenzie and Robinson 1960). However, subsequent studies examined the centrality of face-to-face communication in the context of postcolonial authoritarianism. Stephen Ellis argues that when mass media are censored and government controlled, news is 'broadcast' over 'pavement radio', or by word of mouth (Ellis 1989). In this context, interpersonal communication carries rumor and is potentially subversive. Angelique Haugerud emphasizes the importance of the baraza or government-convened public meetings (Haugerud 1995). At these meetings, social hierarchies are displayed, and thus, are reproduced. Explicit dissent is kept off-stage, but tacit dissent becomes a weapon of the weak.

An expansive literature has studied electioneering in sub-Saharan Africa since the third wave of democratization. Numerous studies examine when and how African parties engaged in clientelist exchanges with citizens (Kramon 2017). Others examine when and how parties appeal to citizens' ethnic identities (Cheeseman and Larmer 2015). Others still contend that parties win support by making valence appeals (Bleck and van de Walle 2018). A parallel literature studies which appeals voters are most receptive to (Lindberg 2013), and implicitly, which appeals are most effective. Others still study parties' deployment of particular discourses such as populism (Cheeseman and Larmer 2015; Larmer and Fraser 2007) or nationalism (Beresford 2012). However, by concentrating on discourse and appeals, these studies focus on the content of the 
messages that parties craft, rather than on the means by which they impart those messages (Paget 2019a). Relatedly, studies attribute electoral success almost exclusively to the selection and delivery of particular messages (Beresford 2012; Cheeseman and Larmer 2015; Kramon 2017; Larmer and Fraser 2007) rather than, for example, disparities in their ground campaigns.

In this respect, the recent Africanist literature differs markedly both from the comparative literature and from the preceding generation of Africanist studies. There is a fast-growing parallel literature about how mobile phones and social media are changing African media environments (Srinivasan and Diepeveen 2018; Srinivasan, Diepeveen, and Karekwaivanane 2018; Wasserman 2011). However, there is little systematic treatment of the means and media through which African political parties convey their messages in the campaign. In particular, there is little consideration of the character or structure of the ground campaign. The treatment of ground campaigns is limited to descriptions of leaders' rallies (Bleck and van de Walle 2018; Foucher 2007; Larmer and Fraser 2007; Tendi 2013) and observations of the form that rallies have an 'entertainment component' (Bob-Milliar 2014). Some recent studies examine ground campaigns in further depth. However, they focus primarily on targeting strategy (Brierley and Kramon 2018; Cheeseman, Lynch, and Willis 2017; Horowitz 2016; Rauschenbach 2017). I seek to restore the prominence and variety of the ground campaign to the study of electoral mobilization in subSaharan Africa. I do so by locating many African elections, and others across the globe, in a truly comparative typology of campaign ecologies.

\section{The rally-intensive campaign}

The authors of the aforementioned typologies are clear that their schemas should be able to conceptually accommodate all election campaigns. Farrell and Webb state that 'our threefold typological device is therefore essentially a heuristic device, a classificatory scheme of ideal-types' 
(Farrell and Webb 2000:106). Campaigns should only sit displaced from that continuum as real examples deviate from ideal-types. These ideal-types 'should... be seen as a continuum along which organizations are moving - from a "premodern" pole to an "advanced-modern" pole" (Farrell and Webb 2000:106). Similarly, Norris states that 'contests can continue to be arrayed from the premodern to the postmodern' (Norris 2000:140). Deviations of particular campaigns from the features of these types should be explained by reference to 'mediating', and therefore implicitly secondary, factors (Norris 2000:151). Therefore, these typologies build-in strong judgements about which sorts of variation in campaigns to privilege and which sorts to trivialize, which to treat as significant and which to treat as insignificant. Among other things, they trivialize the rally; for them, the incidence or absence of the rally is only pertinent to the categorization of ground campaigns as a constitutive part of the election campaign. In effect, ground campaigns are homogenized in these schemas.

Even Plasser and Plasser treat ground campaigns as homogeneous. Like other authors in this canon, they invariably refer to rallies, canvassing and other aspects of the ground campaign together, as one bundle of associated campaign activities. Describing Indian campaigning, they write that 'traditional campaign practices like mass rallies and canvassing drives prevail' (Plasser \& Plasser, 2002:279). In a telltale sign, they describe ground campaigns as 'premodern' (Plasser \& Plasser, 2002:278). Therefore, at best, they treat heterogeneity in ground campaigns as insignificant.

This is my point of departure from the comparative literature on election campaigning. In some ground campaigns, few people are reached directly at rallies. Rallies are employed by leaders to win and stylize media coverage (Cohen and Powell 2005; Jones 1998). However, in most contemporary Western countries, candidates present themselves at mass meetings to just a slither of their electorates (Dalton, McAllister, and Wattenberg 2000). For example, in the 2012 
elections in the United States, just 5.6\% of respondents attended rallies ${ }^{\mathrm{iii}}$, even though leaders' rallies are frequently covered on mass media. This is not a sign of the decline of ground campaigning in general. On the contrary, the evidence suggests that Western ground campaigns are flourishing (Beck and Heidemann 2014). Nonetheless, rallies are marginal in these ground campaigns. In other ground campaigns, the rally is the primary means throughout which parties interact with voters directly. Therefore, in these campaigns, rallies form a significant part of parties' perennial political communication goals: to multiply and target campaign contact (Epstein 2018: 7) for the ostensible purpose of persuading and mobilizing citizens (Nielsen 2012).

I define the rally as a public event at which speakers address an audience face-to-face for the ostensible purpose of politically mobilising it. Publicness distinguishes the rally from internal meetings. The format of speaker and audience distinguishes the rally from the other forms of campaign contact such as the canvass. It also suggests how to distinguish rallies from other mass political events such as marches and parades; insofar as they do not feature speakers addressing audiences, they are not rallies. The purpose of mobilisation distinguishes the rally from the lecture and the sermon.

Nowhere is the preponderance of the rally greater than in sub-Saharan Africa. In the 30 subSaharan countries surveyed in the Fifth Round of the Afrobarometer, the average country rate of rally attendance was $40.6 \%$. In thirteen countries, it was $45 \%$ or greater. A breakdown of these results is presented in Figure 1. Despite the possibility that social desirability bias inflates these answers, this scale of rally attendance cannot be stressed enough. Across the countries surveyed, on average, more than three times as many people attended a rally at the last election as asked a government official for help in the last year. Equally, more than three times as many people attended a rally at the last election as took part in a demonstration or protest in the last year. ${ }^{\text {iv }}$ By 
overlooking the preponderance of rallies, the literature has under-appreciated an essential feature of the structure of many African campaigns.

[Figure 1 about here]

These towering rates of rally attendance are mirrored elsewhere. The Third Wave of the Asian Barometer shows that the proportion of people that attend a 'rally or political party meeting' reaches peaks of 42 per cent in Cambodia, 50 per cent in Thailand, 55 per cent in Mongolia and 65 per cent in Vietnam. ${ }^{\mathrm{v}}$ While any portion of these figures may represent in-door or memberonly party meetings, rather than public rallies which are open to all, they nonetheless offer a strong initial indication of the scale of rally attendance.

[Figure 2 about here]

Aggregate rates of rally attendance also varied across Western 'premodern' campaigns. British platform speaking only became commonplace after William Gladstone’s first Midlothian campaign in 1879 (Meisel 2001). Even then, it remained primarily the preserve of party leaders. Similarly, in the United States, 'stumping' was privileged in some campaigns and neglected in other 'front-porch' campaigns (Boller 1996). Changes in transportation, amplification and the franchise made campaigns in the Western world more rally-intensive from the 1920s to the 1940s. For example, in 1879, Gladstone addressed an unprecedented 90,000 people over 30 meetings (Meisel 2001). Fifty years later, Stanley Baldwin addressed an estimated 200,000 people at a single meeting (Lawrence 2009:107). Consequently, rallies became vital to campaigning. In the United States, Calvin Coolidge did not take to the stump in the 1924 campaign. However, every subsequent Republican and Democratic candidate did so vigorously until 1952 (Boller 1996). 
During the interwar period, junior candidates convened more rallies too. Jon Lawrence suggests that there was a late 'golden age' of the rally at the constituency-level in Britain (Lawrence 2009). Paula Cossart describes the ascendance of the meeting-cum-demonstration in France (Cossart 2013). Therefore, premodern campaigns varied in rally-intensiveness in the very countries which served as the evidential basis of existing typologies of election campaigns.

Neither Norris' three campaign types, nor Plasser and Plasser's five campaign styles, adequately capture the profound differences between these ground campaigns. However, if creatively revised, Norris' schema could. Incorporating this variation involves unbundling features of the campaign, and this in turn involves shedding the typology of its modernist features. This creates different conceptual challenges. Norris takes the degree of modernity as a defining feature of each campaign type. This modernity is embodied in eight different types of features which vary across each type of campaign (Norris 2000: 138-9). Without modernity as an organizing concept, one must reconsider which of these eight features, or what at all, defines a campaign type. This dilemma is only exacerbated by the growing body of evidence that the relationships between each of these campaign features are complex. Many of the close associations, for example, between campaign ecology and party organization, which may have seemed compelling when they were first advanced, have been challenged since. These old certainties have given way to studies that identify significant variation within the same types of campaigns (Plasser and Plasser 2002; Vaccari 2013). Therefore, typologies that theoretically bundle numerous features together have become more difficult to defend as empirical generalizations.

In recognition of these complications, I curtail some of the claims involved in this adapted typology, and taper others. I focus on the campaign ecology, defined as the channels, media and other means through which political messages travel. I take the campaign ecology as definitive of 
the campaign. Farrell and Webb disparage these 'mechanics' as a reductive basis for a rounded characterization of a campaign (Farrell and Webb 2000:103). However, by elaborating this adapted typology, I do not feign to offer a rounded or a complete characterization of campaigns. Indeed, campaigns are too complex and multifaceted to be sufficiently characterized by a few, or perhaps even a host of features. Instead, I adopt the more modest goal of elaborating the key features of campaign ecology. I recategorize the other seven aspects of the campaign that Norris enumerates as typical features which are often, but not always, associated with campaign ecologies. Thereby, I seek to retain the reach of Norris' terminology, while laying the conceptual ground work that will enable the interrogation of the links between campaign ecologies and those other features.

This reworking of Norris' schema involves distinguishing between campaign ecologies on two dimensions. The first is the proportion of campaign contact which is made indirectly through mass media, or as Jesper Strömbäck describes it, the first aspect of campaign 'mediatization' (Strömbäck 2008). The second is the degree to which media channels proliferate, media becomes participatory, and media fuse, or what one might describe, borrowing from Andrew Chadwick, as media hybridity (Chadwick 2013). As this adaptation relieves the typology of its modernist underpinnings, I have taken the liberty of suggesting different names for the associated campaign ecologies. These new names shear the campaigns of their modernist terminology, but remain true to the essence of Norris' ideal-types in other respects: the ground-intensive campaign ecology (premodern), the mass media-intensive campaign ecology (modern), and, borrowing from Andrew Chadwick, the hybrid campaign ecology (postmodern). These campaign ecologies are home to corresponding campaign types: ground-intensive campaigns, mass media-intensive campaigns and hybrid campaigns. In the interests of good prose, I refer to these ecologies and corresponding campaign types interchangeably hereafter. This is set out in the first part of Figure 3. 
To express the differences in electioneering which I have described, I propose distinguishing between campaign ecologies on a third dimension: the rally-intensiveness of the ground campaign. Hereby defined, the higher aggregate rally attendance climbs, the more rally-intensive the ground campaign becomes. The ground campaign is a component of every election campaign, and so 'rally-intensiveness' is a dimension along which campaign ecologies can be placed. This criterion captures campaigns such as those described above, where rallies are a means to directly reach large numbers of people. However, it excludes campaigns in which leaders convene rallies to win or shape media coverage, but do not reach many people directly. This new dimension creates the conceptual space to plot a distinct ideal-type: the rally-intensive campaign ecology. Rally-intensive campaigns are those in which the ground campaign is rallyintensive and the campaign as a whole is ground campaign-intensive. This third dimension and fourth ideal-type are illustrated in the second part of Figure 3 below. Neither this category, nor this typology, is Africa-specific. Rally-intensive campaigns can be found across the globe. However, it is likely that most contemporary rally-intensive campaigns are in sub-Saharan Africa, and that the most emblematic examples are African.

[Figure 3 about here]

At first sight, rally-intensiveness may not appear to be an aspect of campaign ecology. Unlike television penetration or channel proliferation, rally-intensiveness is not a 'hard', technological factor. However, as many have argued, technologies themselves are social (Chadwick 2013). Campaign mediatization, for example, depends in part on changing habits of media use for news and leisure (Herbert 2004). Equally, it depends upon the construction of 'the news', media authority and media trustworthiness. This is why the term 'campaign ecology' characterizes the 
aspect of the campaign in question better than 'campaign environment'. It involves patterned interactions between actors, the very essence of an ecology.

\section{Rally-intensive campaigning in Tanzania}

One might distinguish between campaigns across endless possible dimensions. If typologies of campaigns are to recognize aggregate rally attendance as a significant dimension of campaign ecology, aggregate rally attendance should be consequential. In this section, I enumerate four features that stem from the rally-intensiveness of a campaign, features that typify, but are not definitive of, rally-intensive campaigns. I do so by examining electioneering in Tanzania. Tanzania has the best-attended election campaign rallies in sub-Saharan Africa, and to the best of my knowledge, the world. Table 1 shows that in 2010, 74\% of Tanzanians attended campaign rallies, a higher rate than anywhere else on the continent. Original survey data presented below shows that $69 \%$ of all Tanzanians attended rallies in the last month of the election campaign in 2015 alone. ${ }^{\text {vi }}$ Nationwide, that amounts to 15.76 million of the country's 22.75 million registered voters. ${ }^{\mathrm{vii}}$ This giddy proportion is only marginally smaller than the $77 \%$ of respondents that report regularly receiving radio news, and much less than the proportion that receive regular news from any other mass medium..$^{\text {viii }}$

I select the Tanzanian case because of its extremity, to borrow Bent Flyvberg's term (Flyvbjerg 2006). The accentuated rally-intensiveness of Tanzania's campaigns makes its characteristics particularly pronounced. By studying them, I can distil four features of the rally-intensive campaign. This creates issues of external validity which this case study cannot resolve altogether. While there are signs that these four features can be found in other rally-intensive campaigns, I cannot verify how well this theory travels. How well it does, and how intervening variables mediate its travel, should be the subject of further research. 
First, unlike ground-intensive campaigns as defined above, in rally-intensive campaigns local candidates convene rallies as frequently as national candidates do. Second, unlike groundintensive campaigns, local rallies are better attended in aggregate than national ones. A consequence thereof is that the most common form of campaign contact between mid- and lowlevel politicians and voters is direct, although not always participatory. Third, unlike in groundintensive campaigns, the canvass pales in comparison to the rally as a means of campaign contact. Fourth, and relatedly, local campaigners do not direct most of their efforts to canvassing. Instead, they dedicate a large portion of their efforts to 'producing' rallies.

To explore and describe ground campaigning ethnographically (Hammersley and Atkinson 2007), I conducted eight months of field research in Tanzania, which incorporated the 2015 general election campaign. I focused on the campaigns of parliamentary candidates in eight constituencies. There, I conducted 148 unstructured interviews with candidates, mid-level officials, and low-level activists. I examined campaigning in these constituencies first-hand; I was a latent participant observer at 42 rallies altogether (Spradley 1980). I complement this with data from a representative post-election survey with 1,000 respondents. These methods are described further in the supplementary information file.

First, in Tanzania, candidates of all levels of juniority and seniority dedicate enormous efforts to holding rallies. The two candidates that came first and second in Tanzania's 2015 election, John Pombe Magufuli and Edward Ngoyai Lowassa, held on average 3.3 and 3.6 meetings per day during the last month of their campaigns respectively. ${ }^{\text {ix }}$ Other party leaders were dispatched to convene parallel sets of rallies. However, rallies are not primarily the preserve of party leaders, as they are in other sorts of campaigns. Rival slates of parliamentary candidates toured their constituencies without pause throughout the two-month official campaign. Typically, a candidate 
would hold perhaps three meetings each day, but some, with the aid of helicopters and advance teams, addressed as many as seven meetings on some days. Many candidates planned to visit each village in their constituency two or three times during the campaign. Below parliamentary candidates, ward councilor candidates held their own meetings, riding on parliamentary coat-tails when possible, but conducting most of their rallies independently. Altogether, candidates at each level of seniority dedicate the lion's share of their time during election campaigns to holding meeting after meeting. As a consequence, thousands of candidates address meetings during each day of election campaigns in Tanzania.

Second, more people attend local rallies than national ones. In the survey described above, respondents were asked which parties' rallies they had attended in the last month of the campaign, if any. They were asked whether the most senior politicians that spoke at these meetings were (1) presidential candidates, (2) national politicians, (3) parliamentary candidates, (4) councilor candidates, or (5) other local leaders. Finally, they were asked how many of each they had attended. No other survey has asked questions which disaggregate patterns of rally attendance in such detail, to the best of my knowledge. These results are reported in Table 1 below, summarized across the ruling party, Chama cha Mapinduzi (CCM), the leading opposition party, Chama cha Demokrasia na Maendeleo (Chadema), and all parties combined. The first two categories are folded together into 'national campaign rallies' and the final three categories are folded into 'local rallies'. The results show that national campaign rallies were not the best attended body of campaign rallies; instead, local rallies were. While a weighted $39 \%$ of respondents reported attending CCM's national rallies, 58\% reported attending its local rallies. Similarly, almost 33\% of respondents reported attending Chadema's national rallies, while 35\% reported attending its local ones. Therefore, while national rallies are typically the largest individually, mid- and low-tier candidates address more voters in aggregate 
[Table 1 about here]

This reveals something about the directness of party-voter communication in Tanzania. In the 2015 election, $68.2 \%$ of citizens saw a parliamentary candidate, councilor candidate or other local party leader speak. $48.8 \%$ saw a presidential candidate or other national leader speak. Furthermore, these contacts were frequent. Aggregating the number of reported rally attendances, the average respondent reported attending to $3.4 \mathrm{CCM}$ local rallies and 1.6 Chadema local ones. Equally, they reported attending an average of $1.1 \mathrm{CCM}$ national rallies and 0.6 Chadema national rallies. These attendance rates may be inflated by social desirability bias. Nonetheless, one can conclude with confidence that the majority of Tanzanians saw at least one prospective elected representative with the naked eye during an election campaign. Furthermore, while national rallies are attended by tens or hundreds of thousands of people, local rallies are normally attended by a few hundred. Therefore, during the campaign, a majority of Tanzanians see their local candidates just meters away from them. This does not necessarily make politics more participatory. At the rallies that I observed, candidates took few questions. Parties managed dissent, and controlled whose voices were privileged. Audience participation was often confined to cheering, booing, singing, applauding and displaying party paraphernalia. Excitement was displayed through running and dancing. ${ }^{\mathrm{x}}$ Hostility was displayed through violence. Much like in the barazas of one-party Kenya, dissent was kept off-stage (Haugerud 1995). Attendees bent on displaying their approval or disapproval audaciously wrote messages on banners or brought home-made symbolic objects into the crowd. At one rally, attendees brought a mock coffin bearing a candidate's name. ${ }^{x i}$ Nonetheless, the common proximity of voters and candidates distinguishes the aesthetic and content of citizen-politician interaction in rally-intensive campaigns from other types of campaign. 
Third, Table 1 demonstrates that not only was the rate of rally attendance in Tanzania high; it far surpassed the canvassing rate. As I have written elsewhere (Paget 2019b), the aggregate canvassing rate is high by international standards. $20 \%$ of respondents reported being spoken to face-to-face in the month before the election, comparable to high rates of canvassing in subSaharan Africa, and indeed internationally (Brierley and Kramon 2018; Norris 2000). However, nyumba-kwa-nyumba or 'house-to-house' contact pales in comparison to the frequency with which voters and parties interact through the medium of the rally. In other words, Table 1 shows that in rally-intensive campaigns, rallies dwarf the canvass as a means of campaign contact in Tanzania.

Fourth, local campaign effort is directed primarily to producing rallies, rather than primarily to canvassing. Producing rallies is partly about mobilizing people to attend them. Despite the scale of aggregate rally attendance in Tanzania, parties cannot assume that people will come to their meetings. On the contrary, one Chadema interviewee complained that in their district, 'not many people come to the public rallies' ${ }^{\text {xii }}$ Party branches draw people to their rallies by notifying them when and where rallies will take place. A CCM ward official told me that 'we use branch chairmen of respective places to inform members that we shall be having a meeting, ${ }^{\text {xiii }}$ Often, it is CCM mabalori otherwise known as 'ambassadors' or 'ten-cell leaders', or Chadema msingi or 'foundations' that mobilize in this way. One participant of a CCM focus group explained that 'It is the branch secretary who asks ten-cell leaders to inform the electorate; the ten-cell leaders will go because they know their neighborhood leaders. ${ }^{\text {xiv }}$

In Tanzania, party branches and local campaign networks not only mobilize people to attend the meeting, but staff it as well. A Chadema official explained that 'the meeting is opened by the branch leader'. ${ }^{\mathrm{xv}}$ They physically prepare the grounds for the rally, raising flags, hanging bunting, arranging chairs, and building stages. They bring sufficient supporters to form a nucleus crowd 
that entices others to join. Members of parties' paramilitary wings police rallies and manage disturbance and dissent. Equally, they lay on music and dance that lend meetings a festive atmosphere. These entertainers range from praise singers, to poets, hip hop artists, dancers and choirs, but women's choirs or dancing groups called ngoma are the most typical. Entertainment at such meetings fills most of the time at the beginning and end of a rally.xvi

These performances make rallies festive, not least because a stereo with such power and bass is a rare pleasure which is visibly enjoyed in Tanzanian villages. ${ }^{\text {xvii }}$ Politicians' speeches are often short, and the jubilant atmosphere that party activists work to create draws crowds. Activists enact social rituals which accord the politicians attending meetings status and prestige. For example, politicians are often greeted at meetings with great fanfare. They are rushed by adulating supporters. ${ }^{\text {xviii }}$ They are met by welcome committees. ${ }^{\text {xix }}$ Their arrival is accompanied by the singing of choirs. ${ }^{\mathrm{xx}}$ They are often escorted into the village or neighborhood by a procession or honor guard. ${ }^{\mathrm{xxi}}$ Once assembled, they are flattered by praise singers, ${ }^{\mathrm{xxi}}$ prayed for, ${ }^{\mathrm{xxiii}}$ vouched for by local and national dignitaries, ${ }^{\text {xiv }}$ and given symbolic presents as performative endorsements. ${ }^{\mathrm{xxv}}$ All of these tasks are crucial for the successful production and execution of the rally and they all demand the effort of the 'campaign assemblage' (Nielsen 2012). Accordingly, among the paramount tasks of a local party apparatus in Tanzania is the skillful production of the rally.

\section{Conclusion}

Typologies of election campaigns play critical roles in the study of electoral politics. They periodize histories of electioneering. They bring order to differences in election campaigns in the present. Further still, they delimit the scope of enquiry. Comparative analyses of electioneering in the 'digital age' or the 'postmodern campaign', for example, either make explicit reference to the 
typologies discussed in this article, or use equivalent terms and categories to define their domains of application. In this article, I have argued that existing typologies neglect a vital aspect of election campaigns: their rally-intensiveness. I have proposed a revised typology to incorporate the rally-intensive campaign into a set of campaign ecologies.

This distinction gives expression to some of the differences between election campaigns in the contemporary Western world and the Global South. It creates the conceptual framework to articulate both similarities and differences between campaigns in parts of sub-Sahara Africa, Latin America and Asia. Indeed, evidence suggests that many rally-intensive election campaigns can be found beyond sub-Saharan Africa. Inter-regional differences aside, this framework elucidates a dimension of variation between African election campaigns. Equally, it throws into relief historical changes in electioneering in the Western world. Therefore, the implications of this article are rather grand. I have adapted Norris' typology of election campaigns to internationalize its reach, but equally, I have complicated past classifications of historic election campaigns in the Western world.

Electioneering in Tanzania illustrates why the rally-intensive campaigns merit recognition as a distinct type of campaign ecology which differs from others, and in particular, differs from ground-intensive (premodern) campaign ecologies. In rally-intensive campaigns, such is the scale of aggregate rally attendance that canvassing constitutes only a minority of direct campaign contact. In rally-intensive campaigns, not only party leaders address meetings; candidates at every level of the party do. Furthermore, in aggregate, more people attend local rallies than national ones. Accordingly, a large portion of party-voter interaction in rally-intensive campaigns is direct, although it may not be as participatory as in the ground-intensive or 'premodern' campaign. In rally-intensive campaigns, local effort is directed differently. Local campaign networks are tasked 
not only with canvassing. They direct enormous efforts to a variety of activities described here as the 'production of rallies.'

This article is also revealing about changes in the structure of campaign communication in Tanzania. In 1989, in the twilight years of the postcolonial era, Ellis identified 'pavement radio', or chains of inter-personal discussion, as the primary means by which current affairs was 'broadcast' in sub-Saharan Africa (Ellis 1989). Thirty years on, those oral cultures of news and discussion persist, not least in Tanzania. However, they live alongside oral cultures of mass meetings which have taken on varied forms in multiparty regimes. The prominence of the mass rally is a crucial component of the altered structure of electioneering across much of the continent and, thus, deserves to be understood and studied in its own right. 
Figure 1: National rates of rally attendance in sub-Saharan Africa

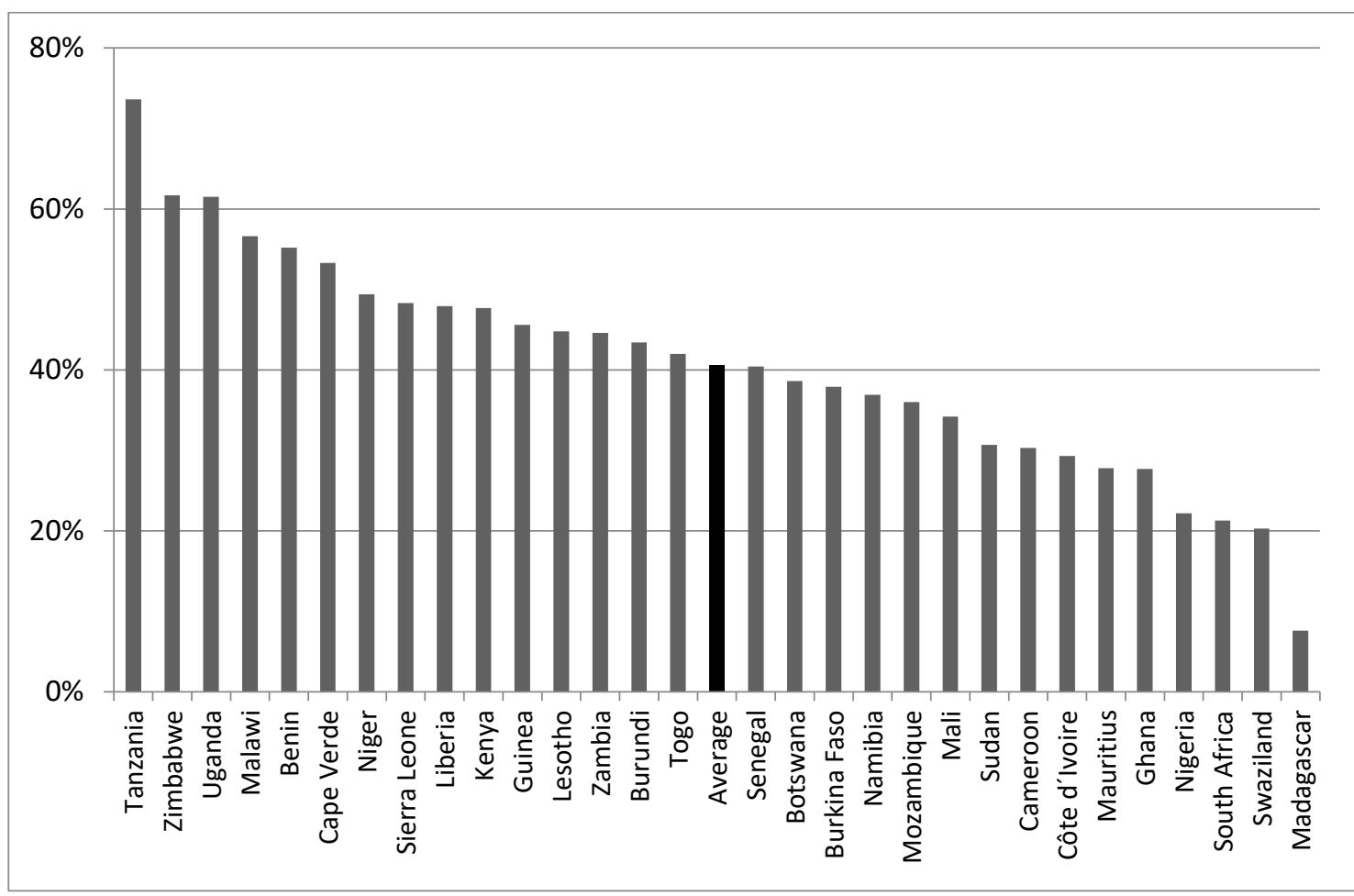

Source: Afrobarometer ${ }^{\mathrm{xxvi}}$ 
Figure 2: National rates of rally and party meeting attendance in Asia

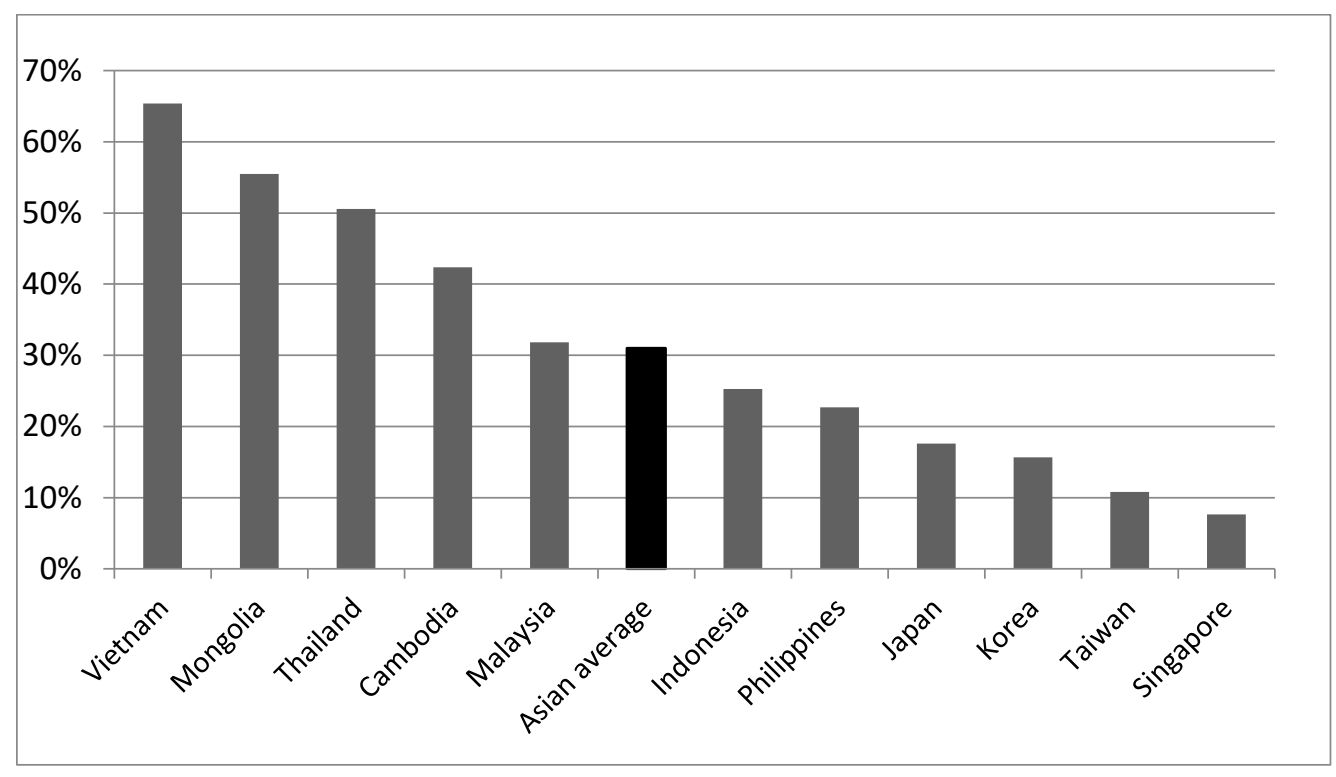

Source: Asia Barometer, Third Wave xxvii $^{\mathrm{x}}$ 
Figure 3: A reworked schema of election campaign ecologies

A revision of Pippa Norris' schema of election campaigns, organised along two dimensions and replacing campaigns with campaign ecologies.

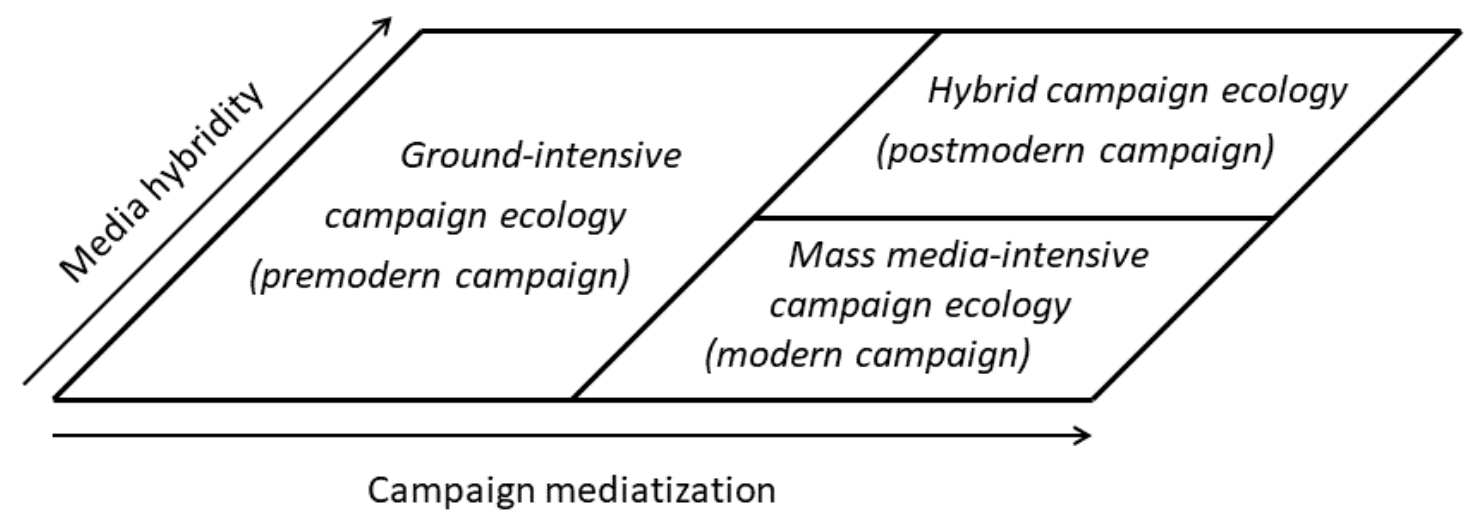

A revised typology of election campaign ecologies along three dimensions, which includes the rally-intensive campaign ecology.

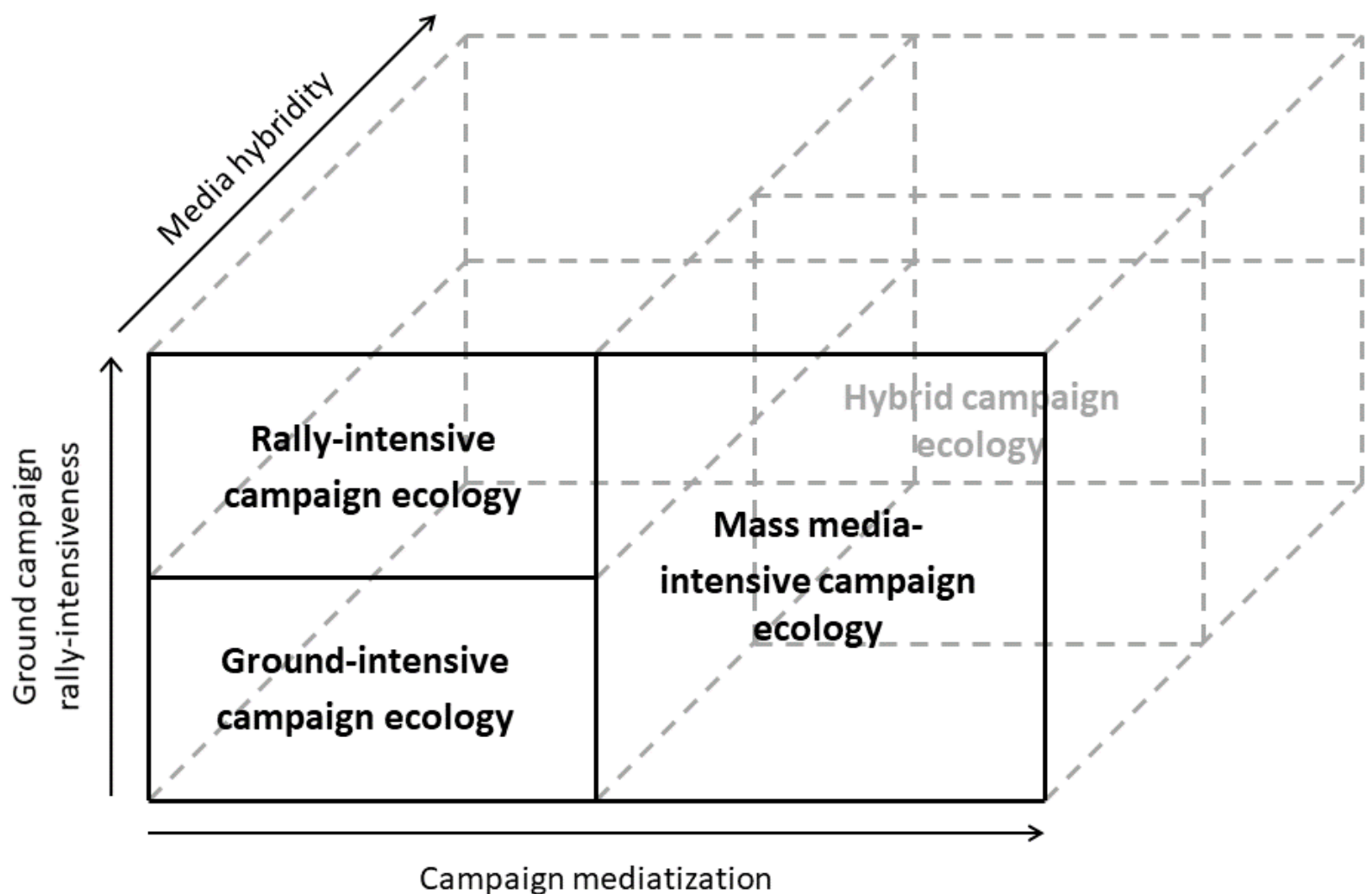


Table 1: Disaggregated campaign contact $^{\mathrm{xxvii}}$

\begin{tabular}{l|l|c|c|c|c} 
& & Proportion & $\begin{array}{c}\text { Standard } \\
\text { error }\end{array}$ & Mean & $\begin{array}{c}\text { Standard } \\
\text { error }\end{array}$ \\
\hline \multirow{2}{*}{ CCM } & Canvassing & $9.9 \%$ & $1.0 \%$ & 0.252 & 0.029 \\
\cline { 2 - 6 } & $\begin{array}{l}\text { National } \\
\text { campaign rallies }\end{array}$ & $39.1 \%$ & $1.8 \%$ & 1.053 & 0.065 \\
\cline { 2 - 6 } & Local rallies & $57.8 \%$ & $2.0 \%$ & 3.370 & 0.160 \\
\hline \multirow{2}{*}{ Chadema } & Canvassing & $11.8 \%$ & $1.2 \%$ & 0.281 & 0.030 \\
\cline { 2 - 6 } & $\begin{array}{l}\text { National } \\
\text { campaign rallies }\end{array}$ & $32.7 \%$ & $2.3 \%$ & 0.618 & 0.051 \\
\cline { 2 - 6 } & Local rallies & $35.0 \%$ & $1.7 \%$ & 1.639 & 0.097 \\
\hline & Canvassing & $20.0 \%$ & $1.4 \%$ & 0.565 & 0.048 \\
\cline { 2 - 6 } & $\begin{array}{l}\text { National } \\
\text { campaign rallies }\end{array}$ & $48.8 \%$ & $1.85 \%$ & 1.826 & 0.095 \\
\cline { 2 - 6 } & Local rallies & $68.2 \%$ & $1.92 \%$ & 5.49 & 0.219
\end{tabular}




\section{Bibliography}

Al Jazeera. 2019. "Half a Million Attend Opposition Rally to Remove India’s Modi.” Al Jazeera, January 19.

Beck, Paul, and Erik Heidemann. 2014. "Changing strategies in grassroots canvassing: 19562012." Party Politics 20(2): 261-274.

Beresford, Alexander. 2012. "The Politics of Regenerative Nationalism in South Africa." Journal of Southern African Studies 38(4): 863-84.

Bleck, Jaimie, and Nicolas van de Walle. 2018. Electoral Politics in Africa since 1990 Continuity in Change. Cambridge: Cambridge University Press.

Blumler, Jay, and Dennis Kavanagh. 1999. “The Third Age of Political Communication: Influences and Features." Political Communication 16(3): 209-30.

Bob-Milliar, George. 2014. "Party Youth Activists and Low-Intensity Electoral Violence in Ghana: A Qualitative Study of Party Foot Soldiers' Activism.” African Studies Quarterly 15(1): $125-52$.

Boller, Paul. 1996. Presidential Campaigns. Oxford: Oxford University Press.

Brierley, Sarah, and Eric Kramon. 2018. Party Campaign Strategies: Rallies, Canvassing and Handouts in Ghana. Self-published work paper. Retrieved (https://www.sarahbrierley.com/uploads/2/7/7/1/27711295/bk_campaigns_25jun18.pdf)

Chadwick, Andrew. 2013. The Hybrid Media System: Politics and Power. Oxford: Oxford University Press.

Cheeseman, Nic, and Miles Larmer. 2015. "Ethnopopulism in Africa: Opposition Mobilization in Diverse and Unequal Societies.” Democratization 22(1): 22-50.

Cheeseman, Nic, Gabrielle Lynch, and Justin Willis. 2017. “Ghana: The Ebbing Power of Incumbency." Journal of Democracy 28(2): 92-104. 
Cohen, Jeffrey, and Richard Powell. 2005. "Building Public Support from the Grassroots Up: The Impact of Presidential Travel on State-Level Approval.” Presidential Studies Quarterly 35(1): 11-27.

Cossart, Paula. 2013. From Deliberation to Demonstration. Political Rallies in France, 1868-1939. Colchester: ECPR Press.

Dinkin, Robert. 1989. Campaigning in America. A History of Electoral Practices. New York: Greenwood Publishing.

Ellis, Stephen. 1989. “Tuning In to Pavement Radio.” African Affairs 88(352): 321-30.

Epstein, Ben. 2018. The Only Constant Is Change: Technology, Political Communication, and Innovation Over Time. Oxford: Oxford University Press.

Farrell, David, and Paul Webb. 2000. "Political Parties as Campaign Organizations.” In Parties Without Partisans: Political Change in Advanced Industrial Democracies eds. Russell Dalton and Martin Wattenberg. Oxford: Oxford University Press, 102-28.

Foucher, Vincent. 2007. "Blue Marches: Public Performance and Political Turnover in Senegal." In Staging Politics: Power and Performance in Asia and Africa, eds. Julia Strauss and Donal Cruise O’Brien. London: I.B. Tauris.

Flyvbjerg, Bent. 2006. "Five Misunderstandings About Case-Study Research.” Qualitative Inquiry 12(2): 219-45.

Gerring, John. 2012. “Mere Description.” British Journal of Political Science 42(4): 721-46.

Gibson, Rachel, and Andrea Rommele. 2001. "Changing Campaign Communications: A PartyCentered Theory of Professionalized Campaigning." Harvard International Journal of Press/Politics 6(4): 475-507.

Gibson, Rachel, Andrea Römmele, and Stephen Ward. 2004. Electronic Democracy: Mobilisation, Organisation and Participation via New ICTs. London: Routledge.

Hammersley, Martyn, and Paul Atkinson. 2007. Ethnography: Principles in Practice. Abingdon: Taylor \& Francis. 
Haugerud, Angelique. 1995. Politics of Culture in Modern Kenya. Cambridge: Cambridge University Press.

Herbert, Stephen. 2004. A History of Early Television. Abingdon: Routledge.

Horowitz, Jeremy. 2016. “The Ethnic Logic of Campaign Strategy in Diverse Societies: Theory and Evidence from Kenya." Comparative Political Studies 49(3): 324-56.

Jones, Jeffrey. 1998. "Does Bringing out the Candidate Bring out the Votes?" American Politics Quarterly 26(4): 395-419.

Karlsen, Rune. 2010. “Does New Media Technology Drive Election Campaign Change?” Information Polity 15(3): 215-25.

Kramon, Eric. 2017. Money for Votes: The Causes and Consequences of Electoral Clientelism in Africa. Cambridge: Cambridge University Press.

de la Torre, Carlos, and Catherine Conaghan. 2009. "The Hybrid Campaign.” The International Journal of Press/Politics 14(3): 335-52.

Larmer, Miles, and Alastair Fraser. 2007. "Of Cabbages and King Cobra: Populist Politics and Zambia’s 2006 Election.” African Affairs 106(425): 611-37.

Lawrence, Jon. 2009. Electing Our Masters. Oxford: Oxford University Press.

Lindberg, Staffan. 2013. "Have the Cake and Eat It: The Rational Voter in Africa." Party Politics 19(6): 945-61

Mackenzie, William, and Kenneth Robinson. 1960. Five Elections in Africa. Oxford: Clarendon Press.

Meisel, Joseph. 2001. Public Speech and the Culture of Public Life in the Age of Gladstone. New York: Colombia University Press.

Nielsen, Rasmus Kleis. 2012. Ground Wars: Personalized Communication in Political Campaigns. Princeton: Princeton University Press.

Norris, Pippa. 2000. A Virtuous Circle: Political Communication in Post-Industrial Societies. Cambridge: Cambridge University Press. 
Paget, Dan. 2019a. "Election Campaigns and Political Mobilization." In The Oxford Encyclopedia of African Politics, ed. Nic Cheeseman. Oxford: Oxford University Press, in press.

Paget, Dan. 2019b. “The authoritarian origins of well-organized opposition parties: The rise of Chadema in Tanzania." African Affairs, in press.

Plasser, Fritz, and Gunda Plasser. 2002. Global Political Campaigning: A Worldwide Analysis of Campaign Professionals and Their Practices. Westport: Greenwood Publishing Group.

Rauschenbach, Macha. 2017. Mobilizing Supporters: The Allocation of Campaign Rallies in Ghana's 2012 Elections. Presented at the Annual Meeting of the African Studies Association, Chicago. Shaheen, Kareem. 2018. "Voters Rally behind Erdoğan's Rival as Turkey Goes to the Polls.” The Guardian, June 24.

Spradley, James. 1980. Participant Observation. New York: Holt, Rinehart and Winston.

Srinivasan, Sharath, and Stephanie Diepeveen. 2018. “The Power of the 'Audience-Public': Interactive Radio in Africa.” The International Journal of Press/Politics 23(3): 389-412.

Srinivasan, Sharath, Stephanie Diepeveen, and George Karekwaivanane. 2018. "Rethinking Publics in Africa in a Digital Age Rethinking Publics in Africa in a Digital Age." Journal of Eastern African Studies 13(1): 2-17.

Strömbäck, Jesper. 2008. "Four Phases of Mediatization: An Analysis of the Mediatization of Politics.” The International Journal of Press/Politics 13(3): 228-46.

Szwarcberg, Mariela. 2012. "Uncertainty, Political Clientelism, and Voter Turnout in Latin America: Why Parties Conduct Rallies in Argentina." Comparative Politics 45(1): 88-106. Tendi, Blessing Miles. 2013. “Robert Mugabe’s 2013 Presidential Election Campaign.” Journal of Southern African Studies 39(4): 963-70.

Vaccari, Cristian. 2013. Digital Politics in Western Democracies. Baltimore: John Hopkins University Press.

Wasserman, Herman. 2011. "Mobile Phones, Popular Media, and Everyday African Democracy: Transmissions and Transgressions." Popular Communication 9(2): 146-58. 


\section{Endnotes}

\footnotetext{
i Epstein's second, third and fourth categories map closely onto the others' three.

ii With the exception of Epstein again, who takes the proliferation of radio, not television, as the advent of the broadcast order.
}

iii This point estimated is weighted and has lower and upper 95 per cent confidence intervals of 4.8 per cent and 6.5 per cent. Data is from the American National Electoral Survey of 2012.

iv Afrobarometer. 2015. “Afrobarometer Data. Round 5. All Countries Surveyed in Sub-Saharan Africa.” Retrieved (http//www.afrobarometer.org/).

v Asia Barometer. 2012. “Asia Barometer Third Wave Data.” Taipei. Retrieved (http://www.asianbarometer.org/).

vi Upper and lower bound 95 per cent confidence intervals of $65.6 \%$ and $73.0 \%$.

vii Upper and lower bound 95 per cent confidence intervals of 14.92 and 16.60 million voters.

viii Upper and lower bound 95 per cent confidence intervals of $74.4 \%$ and $79.1 \%$.

ix These figures were compiled by reports by journalists following the campaigns, who will remain anonymous.

× Rally for Chadema leadership". Field notes. 2015.

xi “Rally for Chadema Presidential Candidate, Edward Lowassa”. Field notes. 2015.

xii Anonymous. 2015a. Interview, Chadema ward chairperson.

xiii Anonymous. 2015b. 2015. Focus Group, CCM member.

xiv Ibid.

xv Anonymous. 2015c. Interview, Chadema ward publicity and ideology secretary and ward elders wing chairperson.

xvi “Rally for Chadema Parliamentary Candidate for Iramba, Jesca Kishoa." Field notes. 2015.

xvii “Rally for CCM’s Parliamentary Candidate for Vwawa Constituency, Japhet Hasunga. Field notes. $2015 \mathrm{a}$.

xviii “Rally for Chadema’s Parliamentary Candidate for Momba Constituency, David Silinde." Field notes. 2015.

xix “Rally for Chadema’s Parliamentary Candidate for Kwimba Constituency, Babila Shilogela.” Field notes. 2015.

xx “Rally for CCM’s Parliamentary Candidate for Vwawa Constituency, Japhet Hasunga.” Field notes. 2015b.

xxi Ibid.

xxii Ibid.

xxiii “Rally for Chadema’s Parliamentary Candidate for Nyamagana, Ezekia Wenje.” Field notes. 2015.

xxiv “Rally for CCM’s Parliamentary Candidate for Vwawa Constituency, Fanuel Mkisi.” Field notes. 2015.

xxv "Rally for Chadema’s Parliamentary Candidate for Ikungi, Tundu Lissu”. Field notes. 2015. 
xxvi Ibid.

xxvii Ibid.

xxviii These figures have been weighted to account for discrepancies in age, gender and region between the survey sample and Tanzania population. National Bureau of Statistics of the United Republic of Tanzania. 2016. "Online Census Database." National Bureau of Statistics. United Republic of Tanzania. Retrieved April 18, 2016 (http://www.nbs.go.tz/nbstz/index.php/english/statistics-by-subject/population-and-housing-census). 